\title{
Upaya Migran Bima Dalam Bekerja (Ngupa Ngaha) Untuk Keberlangsungan Pendidikan Anak
}

\author{
Muhammad Yamin ${ }^{1}$, Ikra $^{2}$, Muhammad Salahuddin ${ }^{3}$ \\ STKIP Harapan Bima ${ }^{123}$, \\ Email: yaminsila@gmail.com ${ }^{1}, \underline{\text { muh.ahlan07@gmail.com }}{ }^{3}$
}

\begin{abstract}
Research problem, becoming a migrant worker has become the goal of the Bima community. In the last few decades, the people of Bima have now depended on themselves to become migrant workers. This includes educating their children. The purpose of this research is, how the efforts of Bima migrants in working for the continuity of children's education. The research method used in this paper is a qualitative approach. The data collection is carried out in two models, namely primary and secondary data collection. Primary data obtained by means of: in-depth interviews (in-depth, interview). Research findings Nggembe Village migrants working in Malaysia have improved their children's education. Achievements in the field of education in 2021 consist of: average length of school and literacy rate. The literacy rate in Nggembe Village continues to increase from 81.4 to 85.80 in 2020 and 94.67 in 2021 or an average increase of $2.7 \%$ annually, while the average length of schooling has increased from 7.2 years in 2019 to 7.3 years in 2021. Conclusion, Nggembe Village migrants working in Malaysia have struggled to the maximum to increase their income with one basic principle, namely wanting to improve children's education
\end{abstract}

Keywords: Migrant Workers, Children of Migrant Workers, Education

\begin{abstract}
Abstrak
Rumusan masalah penelitian, menjadi pekerja migran, telah menjadi cita-cita masyarakat Bima. Beberapa dekade terakhir, masyarakat Bima kini telahmenggantungkan dirinya menjadi buruh migran. Termasuk dalam menyekolahkan anak-anak mereka. Tujuan dari peneltian ini yaitu, bagaimana upaya migran bima dalam bekerja (ngupa ngaha) untuk keberlangsungan pendidikan anak. Metode penelitian digunakan dalam tulisan ini yaitu pendekatan kualitatif. Dalam pengambilan data dilaksanakan dalam dua model yaitu pengambilan data primer dan sekunder. Data Primer diperoleh dengan cara: wawancara mendalam (indepth, interview). Temuan Riset, migran Desa Nggembe yang bekerja di Malaysia telah meningkatkan pendidikan anak mereka. Pencapaian dalam bidang pendidikan pada tahun 2021 terdiri dari: ratarata lama sekolah dan angka melek huruf. Angka melek huruf Desa Nggembe terus meningkat dari tahun 2019 sebesar 81,4 menjadi 85,80 pada tahun 2020 dan 94,67 pada tahun 2021 atau rata-rata naik sebesar 2,7\% setiap tahunnya, sedangkan rata-rata lama sekolah mengalami peningkatan dari 7,2 tahun pada tahun 2019 menjadi 7,3 tahun pada tahun 2021. Kesimpulan, migran Desa Nggembe yang bekerja di Malaysia telah berjuang dengan maksimal untuk meningkatkan pendapatan dengan satu prinsip yang mendasar yaitu ingin meningkatkan pendidikan anak
\end{abstract}

Kata Kunci: Pekerja Migran, Anak Buruh Migran, Pendidikan

\section{PENDAHULUAN}

Menjadi pekerja migran, telah menjadi cita-cita masyarakat Bima. Beberapa dekade terakhir, masyarakat Bima kini telahmenggantungkan dirinya menjadi buruh migran. Pekerja Migran sendiri merupakan objek masyarakat dari satu negara ke negara lain. Mereka tidak terpisahkan dengan era industrialisasi, bahwa saat ini dengan mudah dapat berpindah dari satu tempat ke tempat lain. Dengan kata lain, globalisasi dan integrasi negara-negara di dunia telah meningkatkan pekerja migran melalui cara disebut untuk bermigrasi. Adanya migrasi, masyarakat di suatu negara mempunyai tekad berpindah ke negara lain dengan tujuan mencari nafkah (ngupa ngaha) untuk meningkatkan taraf ekonomi serta pedidikan anak mereka. Sehingga masyarakat tidak lagi tinggal di daerah asal mereka dan mulai menyebar ke daerah-daerah atau negara lain di seluruh dunia.

Pekerja migran dapat dikategorikan sebagai seorang yang bekerja di luar negeri. Dalam dirinya itu, pekerja migran mengharapkan upah/gaji dalam sebuah rusunawa, wisma, perusahaan atau PT yang memiliki kesepakatan dengan PT lain sebagai penyalur tenaga kerja. Hal itu dapat dijadikan sebagai tolak ukur untuk menentukan nasib masa depan pendidikan anak mereka. Salah satu komponen penting untuk mendorong pertumbuhan peningkatan pendidikan anak apabila didorong oleh pendapatan orang tua. Sementara dalam memenuhi kebutuhan pekerja, maka pengusaha 
dalam menetapkan upah harus memperhatikan kebutuhan fisik dan keamanan, kebutuhan sosial, kebutuhan egoistis pekerja (Budijanto, Oki Wahju, 2017).

Hubungan menjadi pekerja migran dan menyekolahkan anak pun termasuk dalam aspek hidup dan cita-cita. Peterson dan Plowman dalam Hasibuan mengatakan bahwa orang mau bekerja karena terdorong oleh beberapa aspek seperti aspek kehidupan (desire to live), aspek keinginan untuk memiliki sesuatu (desire for possession), aspek keinginan atas kekuasaan (desire for power), aspek keinginan untuk pengakuan (desire for recoqnition) (Budijanto, Oki Wahju. 2017). Pekerja migran di Bima menjadi fenomena umum bahwa tujuan menjadi buruh migran untuk mewujudkan cita-cita anaknya untuk sekolah setinggi-tingginya. Orang tua di Bima rela menjadi buruh migran, supaya anaknya tidak seperti dirinya kelak. Kendati upah/gaji yang dihasilkan di daerah sendiri tidak cukup untuk membiayai pendidikan anak dari sekolah dasar sampai ke perguruan tinggi. Apalagi yang memotivasi pekerja migran Bima yaitu pendidikan merupakan salah satu indikator atau capaian kesuksesan. Khususnya di Desa Nggembe Kecamatan Bolo.

Pekerja migran Bima, khusus dari Desa Nggembe memiliki negara tujuan yang beragam. Namun kebanyakan pekerja migran memilih Malaysia sebagai tempat untuk bekerja. Apalagi di tahun 2020 ini, sebanyak 24 orang telah menjadi pekerja migran di Malaysia. Untuk lebih jelas perhatikan data di bawah ini.

Tabel 1 Buruh Migran Asal Bima Desa Nggembe di Malaysia Tahun 2021

\begin{tabular}{r|l|c}
\hline \multicolumn{3}{c}{ No Negara Tujuan Malaysia } \\
\cline { 2 - 3 } & \multicolumn{1}{c}{ Bulan } & Jumlah \\
\hline $\mathbf{1}$ & Januari & $\mathbf{5}$ \\
\hline $\mathbf{2}$ & Februari & $\mathbf{2}$ \\
\hline $\mathbf{3}$ & Maret & $\mathbf{4}$ \\
\hline $\mathbf{4}$ & April & $\mathbf{3}$ \\
\hline $\mathbf{5}$ & Mei & $\mathbf{1}$ \\
\hline $\mathbf{6}$ & Juni & $\mathbf{1}$ \\
\hline $\mathbf{7}$ & Juli & $\mathbf{3}$ \\
\hline $\mathbf{8}$ & Agustus & $\mathbf{2}$ \\
\hline $\mathbf{9}$ & September & $\mathbf{3}$ \\
\hline & Total & 24 \\
\hline
\end{tabular}

Sumber: Data Penelitian yang Diolah oleh Peneliti di Lapangan Tahun 2021

Adapun permasalah banyak migran yang bekerja tujuan Malaysia dan besaran gaji/upah yang didapatkan. Motivasi pekerja migran yaitu dapat mendorong keberlangsungan pendidikan anak mereka agar menjadi anak yang berguna bagi daerah Bima. Karena bila tidak menjadi buruh migran, maka tidak dapat mewujudkan cita-cita pendidikan tersebut. Apalagi lapangan kerja bagi migran Bima tidak tersedia dan bahkan upah/gaji tidak relevan cukup untuk keberlangsungan pendidikan anak mereka sehingga antara pemasukan dan pengeluaran tidak seimbang. Karena pengeluaran lebih besar jika dibandingkan dengan pemasukan sehingga untuk memnbiayai pendidikan anak mereka mulai dari SD, sampai Perguruan Tinggi tidak cukup. Sehingga Migran Bima mencari jalan keluar untuk menjadi migran bima tujuan Malaysia tujuan Malaysia dalam bekerja (ngupa ngaha) untuk keberlangsungan pendidikan anak mereka. Kendati demikian menjadi Migran Bima tujuan Malaysia salah satu upaya yang sangat penting karena di satu sisi akan menjamin nilai tambah karena gaji/upah yang didapatkan lebih besar jika dibandingkan di daerah sendiri karena lapangan kerja terbatas.

Upaya para pekerja migran Bima untuk pergi ke Malaysia pun sangat keras. Apalagi yang memilih menjadi buruh migran yaitu kebanyakan perempuan. Berikut ini, empat upaya yang dilakukan Migran Bima tujuan Malaysia dalam bekerja (ngupa ngaha) sebelum berangkat. Pertama, upaya migran Bima dalam bekerja (ngupa ngaha) yaitu melakukan pelatihan wirausaha, mendirikan organisasi PKK dan PKH sebagai penyalur kreatifitas keluarga Migran. Kedua, upaya migran Bima dalam bekerja (ngupa ngaha) dengan Mengikuti pelatihan seperti belajar tata boga, mengaji, dan kursus. Ketiga, upaya migran Bima dalam bekerja (ngupa ngaha) dengan mengikuti pelatihan seperti membaca, menulis, mendengar dan berdiskusi. Keempat, upaya migran Bima dalam bekerja (ngupa ngaha) dengan mengikuti pelatihan seperti mencuci, memasak, dan mengurus anak (Yamin, 2021).

Berdasarkan uraian di atas, sudah jelas bahwa masalah yang dihadapi oleh migran Bima 
tujuan Malaysia sangat kompleks dan tidak mudah diatasi dengan cara persuasif namun adakalanya harus dilakukan dengan cara-cara preventif. Berdasarkan latar masalah di atas maka tujuan dari peneltian ini yaitu, bagaimana upaya migran bima dalam bekerja (ngupa ngaha) untuk keberlangsungan pendidikan anak?

\section{METODE}

Penelitian yang digunakan dalam tulisan ini yaitu pendekatan kualitatif. Data kualitatif mengandalkan data berupa teks, ciri khas dari metode ini adalah penekanannya pada proses, dimana proses tersebut melihat bagaimana fakta, realita, gejala dan peristiwa itu terjadi dan dialami, secara khusus tentang bagaimana peneliti terlibat di dalamnya dan menjalin relasi dengan orang lain, metode ini menekankan pada persepsi partisipan sebagai kunci utama (Kristin, Esthenberg. 2017).

Dalam pengambilan data dilaksanakan dalam dua model yaitu pengambilan data primer dan sekunder. Data Primer diperoleh dengan cara: wawancara mendalam (indepth, interview). Sugiyono (2010) mengatakan bahwa kegiatan wawancara ini untuk mendapatkan informasi dari para informan dengan cara tatap muka atau bertemu langsung (Sugiyono, 2010). Dalam hal ini, penulis mewawancara pekerja migran dan eks pekerja migran Bima yang ke Malaysia. Sedangkan data sekunder diperoleh dengan cara: a) survei instansi. Survei ini dilakukan terhadap berbagai instansi yang terkait menyangkut keberlangsungan pendidikan anak pekerja migran Bima. b) Studi kepustakaan/literatur. Survei ini berkaitan dengan usaha mendapatkan informasi tentang pekerja Migran di Bima dari jurnal-jurnal, dan lain-lain.

Sementara itu, analisasi data dalam tulisan ini telah dilakukan sejak awal penelitian. Analisis data dilakukan sejak penelitian lapangan, sewaktu pengumpulan data dan setelah semua data terkumpul atau setelah selesai dari lapangan. Analisis data penelitian ini menggunakan lima fase yaitu: (1). Compiling database (kompilasi database), (2) disasembling data (pembongkaran data), (3) reassembling and arraying (pemasangan dan penyusunan data kembali), (4) interpreting (mengartikan data), (5). Concluding (menyimpulkan) (Robert, Yin K,
2011). Untuk lebih jelasnya akan di tunjukan oleh gambar berikut ini:

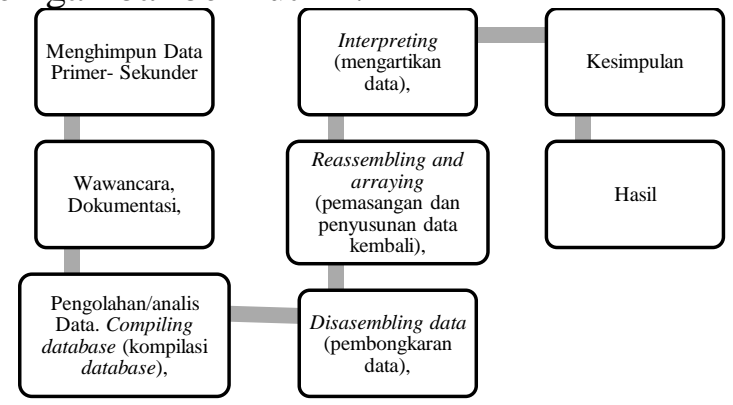

Gambar 1 Metode Analisis Mulai Awal Sampai Akhir Penelitian, Sumber: Yin. 2011. Qualitative Research.

\section{HASIL DAN PEMBAHASAN}

Pendidikan merupakan salah satu komponen penting di Desa Nggembe Kecamatan Bolo, Kabupaten Bima. Pendidikan berperan penting bagi Indeks Pembangunan Manusia (IPM). Pekerja migran memberikan sumbangan utama adanya peningkatan pendidikan. Tujuan menjadi buruh migran untuk mewujudkan citacita anaknya untuk sekolah setinggi-tingginya sangat signifikan. Upah atau gaji yang dihasilkan saat menjadi pekerja migran dapat membiayai pendidikan anak dari sekolah dasar sampai ke perguruan tinggi. Apalagi yang memotivasi pekerja migran Bima yaitu pendidikan merupakan salah satu indikator kesuksesan di Bima. Khususnya juga di Desa Nggembe Kecamatan Bolo.

Tantangan bagi masyarakat Desa Nggembe dalam dunia pendidikan yaitu ada dua poin. Pertama, terbatasnya kemampuan masyarakat dari sisi biaya, terutama yang tergolong miskin untuk melanjutkan pendidikan. Kedua, masih ada masyarakat yang mengalami kesulitan akses sarana pendidikan yang belum merata sehingga membutuhkan biaya transport yang cukup besar untuk menjangkau sarana pendidikan tersebut. Kedua poin tersebut sangat dirasakan oleh masyarakat Bima, khususnya Desa Nggembe. Kendati hambatan pendidikan berat bagi masyarakat terutama golongan menengah ke bawah, maka menjadi pekerja migran alternatifnya. Mereka memilih menjadi pekerja migran, tidak hanya untuk meningkatkan pendapatan, namun sebagai upaya untuk memastikan anaknya untuk mengeyam pendidikan. 
Berdasarkan 24 masyarakat yang menjadi migran baik yang masih berada di luar negeri maupun yang sudah balik desanya, terdapat 11 pekerja migran yang terjaring oleh peneliti dalam mengkonfirmasi tentang peran buruh migran di dunia pendidikan. Untuk lebih jelas terkait 11 pekerja migran yang berhasil dijaring oleh penulis, perhatikan tabel di bawah ini.

Tabel 2 Buruh Migran Desa Nggembe di Malaysia Sepanjang Tahun 2021

\begin{tabular}{c|l|l|l}
\hline No & Nama & Tujuan & Pekerjaan \\
\hline $\mathbf{1}$ & Halimah & Malays & Pembantu \\
\hline $\mathbf{2}$ & Halifah & Malays & Pembantu \\
\hline $\mathbf{3}$ & Hadijah & Malays & Pembantu \\
\hline $\mathbf{4}$ & Mayangsa & Malays & Pembantu \\
\hline $\mathbf{5}$ & Elvira & Malays & Pembantu \\
\hline $\mathbf{6}$ & Iklima & Malays & Pembantu \\
\hline $\mathbf{7}$ & Ayu & Malays & Pembantu \\
\hline $\mathbf{8}$ & Muhamm & Malays & Kelapa \\
\hline $\mathbf{9}$ & Wulandari & Malays & Pembantu \\
\hline $\mathbf{1 0}$ & Siti hawa & Malays & Pembantu \\
\hline $\mathbf{1 1}$ & Irma & Malays & Pembantu \\
\hline
\end{tabular}

Sumber: Data Penelitian yang Diolah oleh Peneliti di Lapangan Tahun 2021

Meningkatkan pendapatan ekonomi dan memenuhi biaya pendidikan untuk anak-anak menjadi bagian dati tujuan menjadi pekerja migran. Tujuan tersebut terintegrasi dengan harapan ekonomi keluarga terdorong. Muhammad bekerja sebagai buruh kelapa sawit di Negara Malaysia merupakan suatu hal yang tidak rapuh baginya, bekerja sebagai buruh kelapa sawitlah yang bisa mereka lakukan kendati gaji yang mereka dapatkan berkisar Rp2 juta sampai Rp3 juta. Hidup terasa hampa bagaikan bayang-bayang fatamorgana. Namun hanya mendapatkan pekerjaan itu yang bisa mendorong kebutuhan keluarga mereka agar kelak menjadi mantan buruh migran yang sukses dipandang oleh orang di kampung. Ketika kembali ke kampung halaman ada orientasi masa depan yang diharapkan seperti membangun usaha dan juga menyekolahkan anak mereka sampai sarjana.

"Menjadi buruh migran tujuan Malaysia itu sangat bagus untuk perkembangan ekonomi keluarga karena hasil yang kami dapatkan ketika kami pulang itu sangat memuaskan dan bahkan bisa menjadi modal untuk usaha selama ini, seperti mendirikan tokoh sembako," (Muhammad diwawancara oleh penulis pada hari Selasa, tanggal 1 Juni).

Pergeseran nilai ekonomi menjadi pemicu bagi sertiap orang untuk berkiprah mengedepankan kepentingan keluarga dari pada kepetingan daerah, nilai dasar perjuangan seseorang tergantung bagaimana mereka menghasilkan gaji/upah untuk kebutuhan keluarga; misalkan gaji Rp4 juta sampai Rp5 juta dapat mendorong buruh migran asal Desa Nggembe untuk sukses, berikut: Sesuai dengan penjelasan mantan buruh migran Bapak Muhammad mengatakan bahwa:

"Hasil pendapatan selama menjadi Buruh Migran di luar Negeri mampu membiayai hidup keluarga saya; juga mampu membiayai kuliah anaknya sampai $\mathrm{S} 1$, serta dapat membeli rumah," (Muhammad diwawancara oleh penulis pada hari Selasa, tanggal 1 Juni).

Pengakuan terhadap peran buruh migran di Bima Desa Nggembe, sayangnya masih terbatas pada soal ketenagakerjaan, bukan pengakuan menyeluruh atas keberadaan buruh migran sebagai manusia utuh dengan hak-hak asasi yang melekat padanya. Menjadi buruh migran, khususnya bagi buruh migran laki-laki merupakan sebuah nilai pokok harus dipenuhi karena tanggung jawab utama adalah laki-laki dari ekonomi dan pendidikan anak, buruh migran asal Desa Nggembe telah menujukan keyakinan mereka dalam mendapatkan kehidupan yang layak bagi keluarganya sehingga tercukupi secara ekonomi dan pendidikan. Sementara buruh migran perempun memiliki kesamaan pandangan. Karena untuk memenuhi kebutuhan ekonomi karena tidak menentunya lapangan kerja, mendorong perempuan untuk menjadi buruh migran, berikut hasil wawancara dengan mantan pekerja migran:

"Menurut saya, orang yang menjadi buruh migran ke Malaysia itu sangat bagus untuk perkembangan ekonominya karena hasil yang kami dapatkan ketika kami pulang itu sangat memuaskan dan bahkan bisa menjadi modal untuk usaha meningkatakan pendidikan anak kami," (Halifah 


\section{diwawancara oleh penulis pada hari Selasa, tanggal 1 Juni).}

Keterbatasan sebuah pilihan di tengah berbagai kendala seperti keterbatasan peluang, minimnya informasi, bekerjanya para calo dan agen pengerah tenaga kerja yang hanya mementingkan pengiriman buruh migran dan kurang bertanggung jawab atas apa yang terjadi, jauhnya fungsi Departemen Tenaga Kerja dengan realitas, kemiskinan yang parah di pedesaan tempat asal mereka, ketidak pastian hukum bagi jenis pekerjaan rumah tangga yang mereka geluti, serta persaingan tidak sehat terhadap tenaga kerja migran yang semakin tidak berkeadilan.

Dari uraian tersebut seseorang pasti mencari cara dan menghalalkan segala sesuatu untuk mendapatkan keingginannya walaupun jalur yang ditempuh berduri dan terjal, buruh migran menunjukan semangat yang cukup luar biasa dalam rangka menjadi seorang buruh migran, namun hal itu menurutnya sesuatu yang bagus karena mampu mendorong ekonomi rumah tangganya. Selama berada di Malaysia gaji/upah yang didapat mereka tabung untuk kebutuhan masa depan hidupya.

"Menjadi buruh migran memang dapat meningkatkan pertumbuhan ekonomi, karena kami bekerja dengan sunguh-sunguh dan memanfaatkan uang yang kami dapat selama berada di luar negeri, hal ini terbukti ketika saya kembali ke kampung halaman mampu merubah kondisi rumah tangga. Karena rumah tangga yang dulunya dari rumah panggung namun saat ini saya sudah mendirikan rumah batu," (Halifah diwawancara oleh penulis pada hari Selasa, tanggal 1 Juni).

Sejahtera secara ekonomi dan terpenuhinya kebutuhan makanan, minuman, serta pakaian merupakan kerangka yang dibangun sebagai wujud dinamika sosial kemansyarakatan. Kebutuhan seseorang tidak pernah terbatas secara ekonomi, apabila kebutuhan yang satu sudah ada maka pasti membutuhkan lagi kebutuhan yang lain begitu seterusnya sampai mengalami kejenuhan secara mendalam, berikut, sesuai dengan penjelasan kepala Desa Nggembe Yusuf mengatakan bahwa:
"Selama saya memimpin Desa tentunya kami menilai kemampuan bagi masyarakat kami sungguh luar biasa menjadi buruh migran karena pandangan mereka bekerja ke luar negeri sangat menguntungkan untuk membantu kebutuhan keluarganya. Fakta yang kami lihat bahwa kebutuhan urusan rumah tangga mereka terpenuhi dengan baik dan setelah pulang dari malaysia mereka membangun rumah serta meningkatkan kualitas pendidikan anak mereka," (Wawancara pada hari Rabu, tanggal 2 Juni).

Pemerintah Desa Nggembe yang telah memberikan dukungan untuk para buruh migran dengan mengeluarkan surat izin. Pemerintah desa memberikan apresiasi terhadap keberhasilan dan peran buruh migran. Karena dapat kita bayangkan ketika kebutuhan ekonomi seseorang terpenuhi sejatinya dapat mengurangi kesenjangan sosial di masyarakat, pemerintah pula akan terbantukan dengan kemauan mereka yang menjadi buruh migran dalam artian bagi mereka yang sukses, sebagai pemerintah Desa Nggembe karena melihat mereka sukses kami cukup bangga dan memberikan penghargaan yang setinggi-tingginya.

Keberadaan seorang buruh di luar negeri merupakan keingginannya masing- masing, tentunya dalam hal itu sewalaupun pekerjaan yang mereka dapatkan tidak sesuai dengan keingginannya tetapi yang terpenting bagi mereka ialah dapat mendatangkan manfaat serta gaji/upah yang terpenuhi oleh Negara yang mereka tuju, berikut; Penjelasan mantan buruh migran Hadijah mengatakan bahwa.

"Selama 12 tahun di Malaysia bekerja di perusahaan tekstil cukup menumbuhkan ekonomi keluarga karena gaji saya disana cukup besar, setelah saya kembali dari Malaysia saya membangun rumah, membeli tanah, dan membuka usaha," (Wawancara pada hari Rabu, tanggal 2 Juni).

Data di atas menunjukan bahwa migran desa nggembe yang bekerja di Malaysia telah berjuang dengan maksimal untuk meningkatkan pendapatan dengan satu prinsip yang mendasar yaitu ingin meningkatkan pendidikan anak mereka. Pendidikan merupakan salah satu faktor yang memegang peranan penting. Pencapaian dalam bidang pendidikan 
pada tahun 2021 terdiri dari: rata-rata lama sekolah dan angka melek huruf. Angka melek huruf Desa Nggembe terus meningkat dari tahun 2019 sebesar 81,4 menjadi 85,80 pada tahun 2020 dan 94,67 pada tahun 2021 atau rata-rata naik sebesar $2,7 \%$ setiap tahunnya, sedangkan rata-rata lama sekolah mengalami peningkatan dari 7,2 tahun pada tahun 2019 menjadi 7,3 tahun pada tahun 2021.

Hal ini menunjukan bahwa walaupun rata rata lama sekolah mengalami peningkatan setiap tahunnya tapi rata-rata tingkat pendidikan masyarakat Desa Nggembe masih belum sampai tamat SMP. Namun tingkat pendidikan anak pekerja migran di Desa Nggembe lebih banyak mengeyam pendidikan tinggi. Dari total keseluruhan anak-anak buruh migran dan mantan buruh migran Desa Ngembbe sebanyak 20 orang. Lebih dari 60 persen mengenyam pendidikan tinggi. Untuk lebih jelasnya dapat dilihat pada tabel berikut"Menjadi buruh migran memang dapat meningkatkan pertumbuhan ekonomi, karena kami bekerja dengan sunguh-sunguh dan memanfaatkan uang yang kami dapat selama berada di luar negeri, hal ini terbukti ketika saya kembali ke kampung halaman mampu merubah kondisi rumah tangga. Karena rumah tangga yang dulunya dari rumah panggung namun saat ini saya sudah mendirikan rumah batu," (Halifah diwawancara oleh penulis pada hari Selasa, tanggal 1 Juni).

Sejahtera secara ekonomi dan terpenuhinya kebutuhan makanan, minuman, serta pakaian merupakan kerangka yang dibangun sebagai wujud dinamika sosial kemansyarakatan. Kebutuhan seseorang tidak pernah terbatas secara ekonomi, apabila kebutuhan yang satu sudah ada maka pasti membutuhkan lagi kebutuhan yang lain begitu seterusnya sampai mengalami kejenuhan secara mendalam, berikut, sesuai dengan penjelasan kepala Desa Nggembe Yusuf mengatakan bahwa:

"Selama saya memimpin Desa tentunya kami menilai kemampuan bagi masyarakat kami sungguh luar biasa menjadi buruh migran karena pandangan mereka bekerja ke luar negeri sangat menguntungkan untuk membantu kebutuhan keluarganya. Fakta yang kami lihat bahwa kebutuhan urusan rumah tangga mereka terpenuhi dengan baik dan setelah pulang dari malaysia mereka membangun rumah serta meningkatkan kualitas pendidikan anak mereka," (Wawancara pada hari Rabu, tanggal 2 Juni).

Pemerintah Desa Nggembe yang telah memberikan dukungan untuk para buruh migran dengan mengeluarkan surat izin. Pemerintah desa memberikan apresiasi terhadap keberhasilan dan peran buruh migran. Karena dapat kita bayangkan ketika kebutuhan ekonomi seseorang terpenuhi sejatinya dapat mengurangi kesenjangan sosial di masyarakat, pemerintah pula akan terbantukan dengan kemauan mereka yang menjadi buruh migran dalam artian bagi mereka yang sukses, sebagai pemerintah Desa Nggembe karena melihat mereka sukses kami cukup bangga dan memberikan penghargaan yang setinggi-tingginya.

Keberadaan seorang buruh di luar negeri merupakan keingginannya masing- masing, tentunya dalam hal itu sewalaupun pekerjaan yang mereka dapatkan tidak sesuai dengan keingginannya tetapi yang terpenting bagi mereka ialah dapat mendatangkan manfaat serta gaji/upah yang terpenuhi oleh Negara yang mereka tuju, berikut; Penjelasan mantan buruh migran Hadijah mengatakan bahwa.

"Selama 12 tahun di Malaysia bekerja di perusahaan tekstil cukup menumbuhkan ekonomi keluarga karena gaji saya disana cukup besar, setelah saya kembali dari Malaysia saya membangun rumah, membeli tanah, dan membuka usaha," (Wawancara pada hari Rabu, tanggal 2 Juni).

Data di atas menunjukan bahwa migran desa nggembe yang bekerja di Malaysia telah berjuang dengan maksimal untuk meningkatkan pendapatan dengan satu prinsip yang mendasar yaitu ingin meningkatkan pendidikan anak mereka. Pendidikan merupakan salah satu faktor yang memegang peranan penting. Pencapaian dalam bidang pendidikan pada tahun 2021 terdiri dari: rata-rata lama sekolah dan angka melek huruf. Angka melek huruf Desa Nggembe terus meningkat dari tahun 2019 sebesar 81,4 menjadi 85,80 pada tahun 
2020 dan 94,67 pada tahun 2021 atau rata-rata naik sebesar $2,7 \%$ setiap tahunnya, sedangkan rata-rata lama sekolah mengalami peningkatan dari 7,2 tahun pada tahun 2019 menjadi 7,3 tahun pada tahun 2021 .

Hal ini menunjukan bahwa walaupun rata rata lama sekolah mengalami peningkatan setiap tahunnya tapi rata-rata tingkat pendidikan masyarakat Desa Nggembe masih belum sampai tamat SMP. Namun tingkat pendidikan anak pekerja migran di Desa Nggembe lebih banyak mengeyam pendidikan tinggi. Dari total keseluruhan anak-anak buruh migran dan mantan buruh migran Desa Ngembbe sebanyak 20 orang. Lebih dari 60 persen mengenyam pendidikan tinggi. Untuk lebih jelasnya dapat dilihat pada tabel berikut.

Tabel 3 Prosentase Tingkat Pendidikan Anak Migran dan Eks Migran Desa Nggembe Tahun 2021

\begin{tabular}{c|c|c}
\hline NO & \multicolumn{2}{c}{ Pro. Pendidikan Anak Migran } \\
\hline $\mathbf{1}$ & SD sederajat & $5 \%$ \\
\hline $\mathbf{2}$ & SLTP sederajat & $10 \%$ \\
\hline $\mathbf{3}$ & SLTA sederajat & $20 \%$ \\
\hline $\mathbf{4}$ & Diploma & $15 \%$ \\
\hline $\mathbf{5}$ & Sarjana & $55 \%$ \\
\hline $\mathbf{6}$ & Tidak/ belum sekolah & $0 \%$ \\
\hline $\mathbf{7}$ & Tidak/ belum tamatan & $0 \%$ \\
\hline
\end{tabular}

Sumber: Data Diolah oleh Penulis, 2021

Data di atas menunjukan prosentase jenjang pendidikan yang dicapai oleh anak buruh migran atau eks migran Desa Nggembe selama orang tuanya mencari nafkah di Malaysia. Oleh karena itu anak migran yang memeperoleh pendidikan tersebut telah mendorong peningkata aktualisasi mutu pendidikan khususnya dalam jenjeng Sekolah Tinggi atau Universitas

\section{KESIMPULAN}

Pendidikan merupakan salah satu komponen penting di Bima termasuk di Desa Nggembe Kecamatan Bolo. Tetapi bagi masyarakat yang ekonomi ke bawah, mengalami kesulitan akses sarana pendidikan. Bagi orang tua yang tidak mampu, memilih menjadi buruh migran untuk mewujudkan cita-cita anaknya untuk sekolah setinggi-tingginya. Upah atau gaji yang dihasilkan saat menjadi pekerja migran diperuntukan membiayai pendidikan anak dari sekolah dasar sampai ke perguruan tinggi. Apalagi yang memotivasi pekerja migran Bima yaitu pendidikan merupakan salah satu indikator kesuksesan di Bima. Khususnya juga di Desa Nggembe Kecamatan Bolo. Jadi migran Desa Nggembe yang bekerja di Malaysia telah berjuang dengan maksimal untuk meningkatkan pendapatan dengan satu prinsip yang mendasar yaitu ingin meningkatkan pendidikan anak mereka. Kendati demikian, prosentase jenjang pendidikan anak buruh migran atau eks migran Desa Nggeme sangat tinggi, yaitu $70 \%$ kuliah di perguruan tinggi dan diploma.

\section{SARAN}

Dalam artikel meruoakan bagian dari upaya inteletual untuk mengisi perdebatan scholar terutama penelitian pekerja migran dan pendidikan. Semoga pembaca memberikan saran yang mebangun untuk perbaikan riset kedepan.

\section{UCAPAN TERIMA KASIH}

Ucapan terima kasih terutama ditujukan kepada pemberi dana penelitian atau donatur. Ucapan terima kasih dapat juga disampaikan kepada pihak-pihak yang membantu pelaksanaan penelitian.

\section{DAFTAR PUSTAKA}

\section{Buku dan Jurnal}

Budijanto, Oki Wahju. (2017). Upah Layak Bagi Pekerja/Buruh Dalam Perspektif Hukum dan Ham (Decent Wages For Laborers In Law And Human Right'S Perspective). Jurnal Penelitian Hukum Dejure, Volume 17, Nomor 3, September.

Kristin, Esthenberg. 2017. Qualitative Methods in Social Research, Mc Graw Hill: New York. Hidayat. 2017. Jurnal HAM Vol. 8 No. 2, Desember.

Sugiyono. 2010. Metode Penelitian Kuantitatif Kualitatif dan $R \& D$, Bandung: Alfabeta.

Robert, Yin K. (2011). Qualitative Research from Start to Finish, New York: The Guilford Press.

Hidayat. 2017. Perlindungan Hak Tenaga Kerja Indonesia di Taiwan Dan Malaysia Dalam Perspektif Hak Asasi Manusia 
(Protection Of Indonesian Workers Rights In Taiwan And Malaysia In Human Rights Perspective). Jurnal HAM Vol. 8 No. 2, Desember.

Hidayat. 2017. Perlindungan Hak Tenaga Kerja Indonesia di Taiwan Dan Malaysia Dalam Perspektif Hak Asasi Manusia (Protection Of Indonesian Workers Rights In Taiwan And Malaysia In Human Rights Perspective). Jurnal HAM Vol. 8 No. 2, Desember.

Hidayat. 2017. Perlindungan Hak Tenaga Kerja Indonesia di Taiwan Dan Malaysia Dalam Perspektif Hak Asasi Manusia (Protection Of Indonesian Workers Rights In Taiwan And Malaysia In Human Rights Perspective). Jurnal HAM Vol. 8 No. 2, Desember.

Hidayat. 2017. Perlindungan Hak Tenaga Kerja Indonesia di Taiwan Dan Malaysia Dalam Perspektif Hak Asasi Manusia (Protection Of Indonesian Workers Rights In Taiwan And Malaysia In Human Rights Perspective). Jurnal HAM Vol. 8 No. 2, Desember

Munadi, Sudji. 2015. Peningkatan Motivasi dan Hasil Belajar Pada Mata Pelajaran Pemograman Dasar Menggunakan Modul Di Smkn 2 Sumbawa. Jurnal Pendidikan Vokasi, Vol 5, Nomor 3,

\section{Wawancara}

Buruh Migran, Muhammad (Diwawancara oleh penulis pada hari Selasa, tanggal 1 Juni)

Buruh Migran, Halifah (Diwawancara oleh penulis pada hari Selasa, tanggal 1 Juni)

Buruh Migran, Hadijah (Diwawancara oleh penulis pada hari Selasa, tanggal 1 Juni)

Kepala Desa Nggembe, Yusuf (Diwawancara oleh penulis pada hari Selasa, tanggal 1 Juni) 